\title{
Identification of 14-3-3-like protein in sugarcane (Saccharum officinarum)
}

\author{
Eiko Eurya Kuramae, Roseli Chela Fenille and Vicente Eugenio de Rosa Jr.
}

\begin{abstract}
In a search of the sugarcane expressed sequence tag (SUCEST) database we located three full-length cDNAs (SCCCLR1022D05.g, SCCCRZ1001D02.g and SCBFLR1026E02.g) encoding the 14-3-3 proteins from sugarcane (Saccharum officinarum). The encoded proteins were identified based on the clustering of the expressed sequence tags and were shown to encode proteins similar to 14-3-3 proteins of other monocotyledonous plants. Cluster SCCCLR1022D05.g was 99\% similar to the maize 14-3-3-like protein (gi|1345587) while cluster SCCCRZ1001D02.g shared 96\% and SCBFLR1026E02.g 94\% similarity with the 14-3-3 protein of rice (gi|7435022). Although 14-3-3 proteins have been reported to be specific to particular species, tissue or organ from which they were isolated, all three sugarcane clusters were found to be expressed in several tissues.
\end{abstract}

\section{INTRODUCTION}

Sugarcane is one of the most important crops in the world and Brazil accounts for $25 \%$ of worldwide production. The genus Saccharum is complex and is characterized by high polyploidy and frequent aneuploidy (Sreenivasan et al., 1987). The Sugarcane Expressed Sequence Tag (SUCEST) genome project has provided expressed sequence tags (ESTs) that should allow the identification of novel genes with specific expression patterns and allow the assignment of gene function to certain cell types. We have used this database to analyze ESTs encoding sugarcane 14-3-3 proteins.

The 14-3-3 proteins (shortened to 14-3-3s) were originally named on the basis of their electrophoretic mobility in starch gel electrophoresis (Moore and Perez, 1967) and have been reported in mammals (Aitken et al., 1992), plants (Hirsch et al., 1992; Brandt et al., 1992), Xenopus (Martens et al., 1992), Drosophila (Swanson and Ganguly, 1992) Dictyostelium discoideum (Knetsch et al., 1997) and yeast (van Heusden et al., 1992). The 14-3-3s are ubiquitous in eukaryotic cells where they are involved in a variety of biological functions.

The 14-3-3s isolated from mammalian brain tissue are cytosolic (Moore and Perez, 1967) and several brain 14-3-3s have been found in neuronal and synaptic membranes, which suggest more specific involvement in neurotransmission. Some 14-3-3s are associated with cell organelles, e.g. in rat liver a cytosolic 14-3-3 protein, mitochondria stimulating factor (MSF), stimulates the uptake of nuclear encoded precursors into the mitochondria and in Arabidopsis thaliana and Zea mays 14-3-3s occur in the nuclei (Bihn et al., 1997).
The functions of 14-3-3s are much more diverse than originally thought and include protein kinase $\mathrm{C}$ regulation (Toker et al., 1990), exocytosis (Morgan and Burgoyne, 1992) and ADP-ribosylation of Ras (Fu et al., 1993), as well as being association with transcription factors that regulate gene transcription (de Ventten and Ferl, 1994). Interaction with proteins and protein kinases is a common mechanism by which 14-3-3s influence many functions (Ferl, 1996) and plant 14-3-3s have been found to be part of a transcription factor complex (de Ventten et al., 1992) and the association of 14-3-3s with the G-box binding factor suggests that these proteins may play a direct role in transcriptional regulation. While no animals have as yet been shown as having 14-3-3s associated with transcriptional factors, a potential nuclear role has been suggested for $14-3-3 \mathrm{~s}$ in yeast ( $\mathrm{rad} 24$ and $\mathrm{rad} 25)$ where they may serve in preventing/regulating DNA damage prior to mitosis (Ford et al., 1994).

The activities of several cytosolic enzymes in plant leaves are responsive for changes in photosynthesis. Thus, in addition to providing catabolic/reductant and anabolic/biosynthetic precursors, changes in photosynthesis trigger the release of signals from the chloroplast to control phosphorylation and the activity of cytoplasmic sucrose-phosphate synthase (SPS), nitrate reductase (NR) and phosphoenolpyruvate carboxylase (PEPc) (Foyer et al., 1995; MacKintosh, 1998). When photosynthesis is active, SPS, NR and PEPc are activated, and this stimulation presumably increases the flux through sucrose synthesis, and also stimulates the pathways of nitrate assimilation and $\mathrm{C} 4$ organic acid synthesis that provide nitrogen and carbon for amino acids. SPS, NR and PEPc are not always regulated in parallel, however, since hormones, water stress, nitrogen and carbon supplies can also modulate the phosphorylation 
and activity of these enzymes. Osmotic stress inactivates NR (Kaiser and Föster, 1989), but a simple phosphorylation-dephosphorylation cycle is not sufficient to explain the control of NR. The inactivation of NR occurs by the phosphorylation of serine-543 (Douglas et al., 1995; Su et al., 1996) which is catalyzed by a calcium-dependent (calmodulin-domain) protein kinase (CDPK) or SNF1-related protein kinase (Bachmann et al., 1996a; Douglas et al., 1997; Douglas et al., 1998), followed by binding of phosphorylated NR to an NR inhibitor protein (NIP) made up of one or more 14-3-3 proteins (Bachmann et al., 1996b; Moorhead et al., 1996) which bind directly to the phosphorylation site of NR. While many proteins have been found to bind to 14-3-3 proteins, plant NR was the first in which a functional 14-3-3s effect (inhibition of phosphorylated NR) was identified in a physiological setting (i.e. the response to inhibition of photosynthesis in leaves). In plants, 14-3-3 proteins are also involved in the regulation of the plasma membrane $\mathrm{H}^{+}$-ATPase (Baunsgaard et al., 1998; Jahn et al., 1997), and have been found to bind to a number of proteins (including VP1 and EmBP1) which mediate abscisic acid-induced gene expression (Schultz et al., 1998). In addition, a bacterially expressed calcium-dependent protein kinase (Arabidopsis CPK-1) has been found to bind to, and be activated by, 14-3-3s (Camoni et al., 1998). There is little information on how many 14-3-3-binding targets exist in plants, or on how the phosphorylation-dependent interactions of 14-3-3s with their diverse binding targets are regulated in cells.

In this paper we present the results of our work in which we identified ESTs in the SUCEST database that have a high similarity to $14-3-3$ proteins from other monocotyledonous plants.

\section{MATERIAL AND METHODS}

The SUCEST project is a cooperative effort between 25 laboratories in the Organization for Nucleotide and Sequence Analysis (ONSA) network supported by Fundação de Amparo à Pesquisa do Estado de São Paulo (FAPESP). Our group has been involved in data mining for ESTs involved in sugarcane defense mechanisms against pathogens and environmental stress (http://sucest.lad.dcc.unicamp.br /private/mining-reports/BF/BF-mining.htm). The 260,781 sugarcane ESTs sequenced were cDNAs prepared from sugarcane tissues and allocated to different libraries, the libraries being as follows: apical meristem (AM), callus (CL), flowers (FL), lateral buds (LB), leaf roll (LR), leaves $\mathrm{LV}$ ), root (RT), leaf-root transition zone (RZ), stem bark (SB), seeds (SD), stem internode (ST) and plantlets infected with Glucoacetobacter diazotroficans (AD) and Herbaspirillum rubrisubalbicans (HR). The cDNAs were prepared from poly adenine polyA + mRNA using the SuperScript plasmid system kit (Gibco-BRL USA) or the ZAP-cDNA synthesis kit (Stratagene USA). Double-stranded cDNA was fractionated and fragments $>1 \mathrm{~kb}$ were used. Sequencing was done using BigDye terminators on an ABI Prism 377 DNA sequencer (Perkin Elmer USA).

The EST clusters were built by alignment using the CAP3 program. The search for 14-3-3 proteins was done using a stringent basic local alignment search tool (BLASP) threshold value of $\mathrm{E}<10^{-143}$. The 14-3-3 protein from the National Center for Biotechnology Information (NCBI) was used as a driver for analysis and aligned by TBLASTN program against the sugarcane EST clusters (http://sucest.lad.dcc.unicamp.br/cgi-bin/prod/blast/form
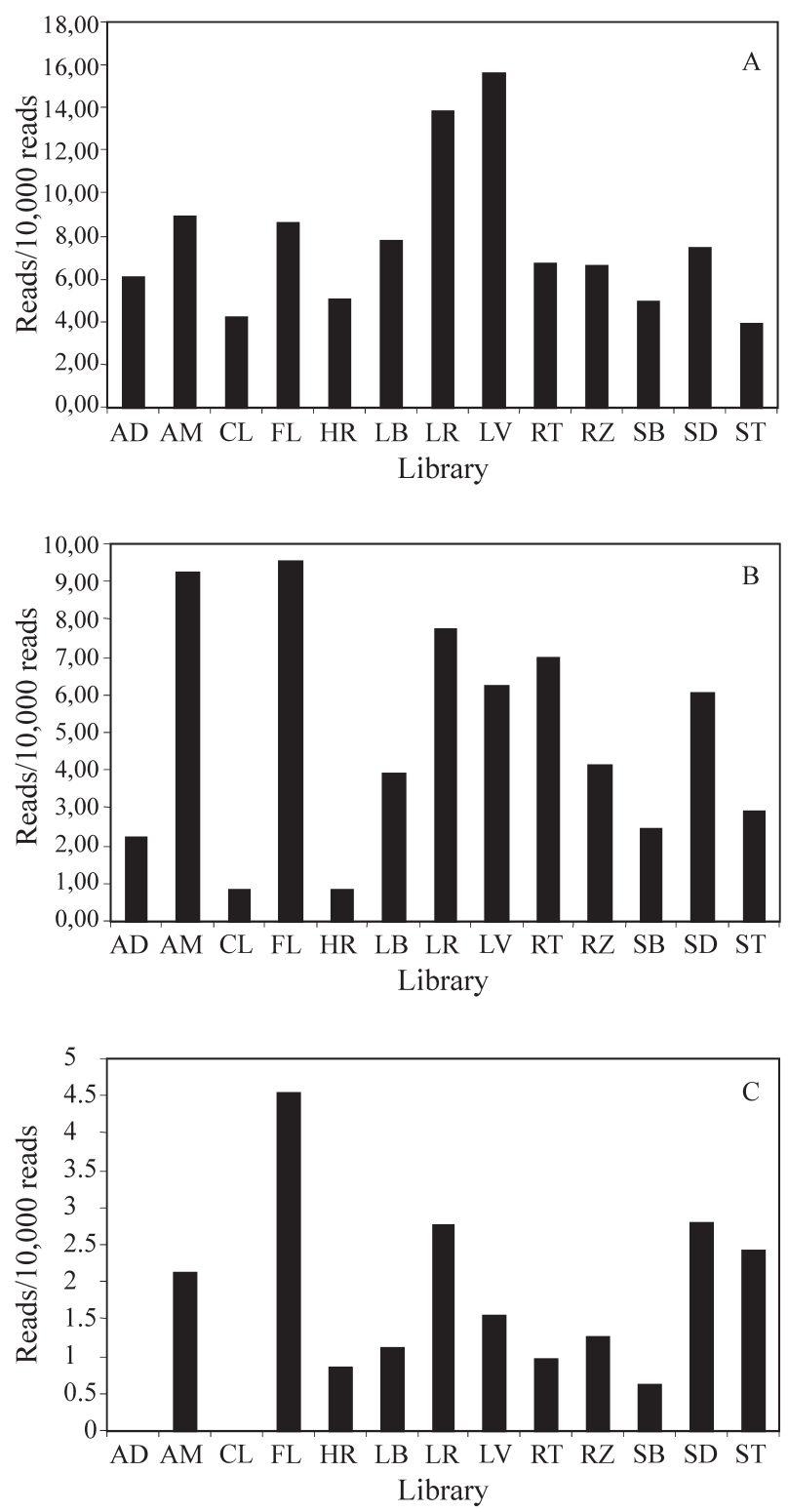

Figure 1 - Percentage of sugarcane cDNA reads per library present in three clusters of 14-3-3 protein. $\mathrm{A}=$ SCCCLR1022D05.g, $\mathrm{B}=$ SCCCRZ1001D02.g, C = SCBFLR1026E02.g. Libraries, AD = plantlets infected with Glucoacetobacter diazotroficans, AM = apical meristem, $\mathrm{CL}=$ callus, $\mathrm{FL}=$ flower, $\mathrm{HR}=$ plantlets infected with Herbaspirillum rubrisubalbicans, $\mathrm{LB}=$ lateral $\mathrm{Bud}, \mathrm{LR}=$ leaf roll, $\mathrm{LV}=$ leaves, $\mathrm{RT}=$ root, $\mathrm{RZ}=$ leaf-root transition zone, $\mathrm{SB}=$ stem bark, $\mathrm{SD}=$ seeds, $\mathrm{ST}=$ stem (internode). 
SCBFLR1026E02.g SCCCRZ1001D02.9 GF14-C 0 . sativa SCCCLR1022D05.g GF14-6 z. mays GF14-12 $z$. mays GF14-b O. sativa 14-3-3 H. vulgare 14-3-3 o. sativa 14-3-3b $H$. vulgare GF14 F. agrestis 14-3-3 I. longiflorum TaWIN1 T. aestivum GF14-d O. sativa

SCBELR1026E02.9 SCCCRZ1001D02.g GF14-C O. sativa SCCCLR1022D05.g GF14-6 z. mays GF14-12 Z. mays GF14-b O. sativa 14-3-3 H. vulgare 14-3-3 O. sativa 14-3-3b $H$. vulgare GF14 F. agrestis 14-3-3 I. longiflorum TaWIN1 T. aestivum GF14-d O. sativa

SCBFLR1026E02.9 SCCCRZ1001D02.g GF14-C O. sativa SCCCLR1022D05.9 GF14-6 2 . mays GF14-12 Z. mays GF14-b O. sativa 14-3-3 H. vulgare 14-3-3 O. sativa $14-3-3 b H$. vulgare GF14 F. agrestis 14-3-3 I. longiflorum TaWIN1 T. aestivum GF14-d O. sativa

SCBFLR1026E02. SCCCRZ1001D02.9 GF14-C 0. sativa SCCCLR1022D05.g GF14-6 Z. mays GF14-12 Z. mays GF14-b O. sativa 14-3-3 H. vulgare 14-3-3 O. sativa 14-3-3b $H$. vulgare GF14 F. agrestis 14-3-3 L. longiflorum TaWIN1 $T$. aestivum GF14-d O. sativa

SCBFLR1026E02.g
SCCCRZ1001D02.g
GF14-C 0. sativa
SCCCLR1022D05.g
GF14-6 Z. mays
GF14-12 Z. mays
GF14-b O. sativa
14-3-3 H. vulgare
14-3-3 O. sativa
14-3-3b H. vulgare
GF14 F. agrestis
14-3-3 L. longiflorum
TaWIN1 T. aestivum
GF14-d O. sativa

------MSREENVYMAKLAEQAERYEEMVEYMEKVAKTVD----VEELTVEERNLLSVAY -----MSREENVYMAKLAEQAERYEEMVEYMEKVAKTVD----VEELTVEERNLLSVAY ------MSREENVYMAKLAEQAERYEEMVEYMEKVAKTVD----VEELTVEERNLLSVAY -MASAELSREENVYMAKLAEOAERYEEMVEFMEKVAKTVD----SEELTVEERNLLSVAY -MASAELSREENVYMAKLAEQAERYEEMVEFMEKVAKTVD----SEELTVEERNLLSVAY -MASAELSREENVYMAKLAEQAERYEEMVEFMEKVAKTVD----SEELTVEERNLLSVAY MSAQAELSREENVYMAKLAEQAERYEEMVEFMEKVAKTVD----SEELTVEERNLLSVAY MSAPGELSREENVYMAKLAEQAERYEEMVEFMEKVAKTVD----SEELTVEERNLLSVAY MSOPAELSREENVYMAKLAEOAERYEEMVE FMEKVAKTVD----SEELTVEERNLLSVAY MAQPAELSREENVYMAKLAEQAERYEEMVEFMEKVAKTVD----SEELTVEERNLLSVAY -MSPAEPSREENVYMAKLAEQAERYEEMVEFMEKVARTVD----TEELTVEERNLLSVAY -MSPAEPSREENVYMAKLAEQAERYEEMVEFMEKVARTVD----TEELTVEERNLLSVAY -MSPAEPTRDESVYMAKLAEQAERYEEMVEFMERVAKATGGAGPGEELSVEERNLLSVAY -MSPAEPTREESVYKAKLAEQAERYEEMVEYMERVARAAGGASGGEELTVEERNLLSVAY

KNVIGARRASWRIVSS IEQKEESRKNEEHVAQIKEYRGKIEAELSNICDGILKLLDSHLV KNVIGARRASWR IVS S IEQKEESRKNEEHVNL IKEYRGKIEAELSNICDG ILKLLDSHLV KNVIGARRASWRIVSSIEQKEEGRGNEEHVTL IKEYRGKIEAELSKICDGILKLLDSHLV KNVIGARRASWRI ISS IEOKEEGRGNEDRVTL IKDYRGKIETELTKICDGILKLLESHLV KNVIGARRASWRIISSIEQKEEGRGNEDRVTLIKDYRGKIETELTKICDGILKLLETHLV KNVIGARRASWRI ISS IEQKEEGRGNEDRVTLIKDYRGKIETELTKICDGILKLLESHLV KNVIGARRASWRI ISS IEQKEESRGNEDRVTL IKDYRGKIETELTKICDG ILKLLESHLV KNVIGARRASWRIISSIEQKEESRGNEDRVTLIKEYRGKIETELSKICDGILKLLETHLV KNVIGARRASWRI ISS IEQKEESRGNEDRCTL IKEYRGKIETELSKICDG ILKLLDSHLV KNVIGARRASWRI ISS IEQKEESRGNEDRVTL IKDYRGKIEVELTKICDGILKLLDSHLV KNVIGARRASWRI ISS IEQKEESRGNEDHVAL IKDYRGKIEAELSKICDGILKLLDSHLV KNVIGARRASWRI ISSIEOKEESRGNEDHVAL IKDYRGKIEAELSKICDGILKLLDSHLV KNVIGARRASWR I IS S IEQKEEGRGNDAHAAT IRSYRSKIEAELAKICDG ILALLDSHLV KNVIGARRASWR I ISS IEQKEEGRGNDAHAAT IRSYRGK IEAELAR ICDG ILALLDSHLV

PSSTAAESKVFYLKMKGDYHRYLAEFKTGTERKESAESTMVAYKAAQDIALAELAPTHPI PSSTAAESKVFYLKMKGDYHRYLAEFKTGAERKESAESTMVAYKAAQDIALAELAPTHPI PSSTAAESKVFYLKMKGDYHRYLAEFKTGAERKEAAESTMVAYKAAQDIALADLAPTHPI PSSTAPESKVFYLKMKGDYYRYLAEFKTGAERKDAAENTMVAYKAAODIALAELAPTHPI PSSTAPESKVFYLKMKGDYYRYLAEFKTGAERKDAAENTMVAYKAAQDIALAELAPTHPI PSSTAPESKVFYLKMKGDYYRYLAEFKTGAERKDAAENTMVAYKAAQDIALAELAPTHPI PSSTAPESKVFYLKMKGDYYRYLAEFKTGAERKDAAENTMVAYKAAQDIALAELPPTHPI PSSTAPESKVFYLKMKGDYYRYLAEFKSGPERKDAAENTMVAYKAAQDIALAELAPTHPI PSSTAPESKVFYLKMKGDYYRYLAEFKTGAERKDAAENTMVAYKAAQDIALAELPPTHPI PSSTAPESKVFYLKMKGDYYRYLAEFKSGTERKDAAENTMVAYKAAQEIALAELPPTHPI PSSTAAESKVFYLKMKGDYHRYLAEFKSGAERKEAAESTLLAYKSAQDIALAELAPTHPI PSSTAPESKVFYLKMKGDYHRYLAEFKSGAERKEAAESTLLAYKSAQDIALAELAPTHP I PSAGAAESKVFYLKMKGDYHRYLAEFKSGGERKEAAESTMNAYKAAQDIALADLAPTHPI PSAGAAESKVFYLKMKGDYHRYLAEFKSGDERKQAAESTMNAYKAAQDIALADLAPTHP I

RLGLALNFSVFYYE I LNS PDKACNLAKQAFDEA ISELDTLGEESYKDSTL IMQLLRDNLT RLGLALNFSVFYYEILNSPDKACNLAKQAFDEAISELDTLGEESYKDSTLIMQLLRDNLT RLGLALNFSVFYYEILNSPDKACNLAKQAFDEA ISELDTLGEESYKDSTLIMQLLRDNLT RLGLALNFSVFYYEILNSPDRACS LAKQAFDEA ISELDTLSEESYKDSTL IMQLLRDNLT RLGLALNFSVFYYEILNSPDRACSLAKQAFDEAISELDTLSEESYKDSTLIMQLLRDNLT RLGLALNFSVFYYE ILNSPDRACS LAKQAFDEAISELDTLSEESYKDSTLIMQLLHDNLT RLGLALNFSVFYYEILNSPDRACNLAKQAFDEAISELDTLSEESYKDSTLIMQLLRDNLT RLGLALNFSVFYYEILNSPDRACNLAKQAFDEAISELDTLSEESYKDSTLIMQLLRDNLT RLGLALNFSVFYYEILNSPDRACNLAKOAFDEAISELDTLSEESYKDSTLIMQLLRDNLT RLGLALNFSVFYYEILNSPDRACDLAKQAFDEAISELDSLSEESYKDSTLIMQLLRDNLT RLGLALNFSVFYYEILNSPDRACNLAKQAFDEAISELDTLGEESYKDSTL IMQLLRDNLT RLGLALNFSVFYYE I LNS PDRACNLAKOAFDEAISELDTLGEESYKDSTL IMOLLRDNLT RLGLALNFSVFYYEILNSPDRACNLAKQAFDEAISELDSLGEESYKDSTLIMQLLRDNLT RLGLALNFSVFYYEILNSPDRACNLAKQAFDEAISELDSLGEESYKDSTLIMQLLRDNLT
LWTSDITEE-GIEEGKEATKG-DAGEGQ
LWTSDLTED-GADEGKEASKG-DAGEGQ
LWTSDLTED-GGDEVKEASKG-DACEGQ
LWTSDISED-PAEEIREAPKR-DSSEGQ
LWTSDISED-PAEEIREAPKR-DSSEGQ
LWTSDISED-PAEEIREAPKH-DLSEGQ
LWTSDISED-TAEEIREAPKR-DSSEGQ
LWTSDITEDTAEEEIREAPKH-DSSEGQ
LWTSDISED-AAEEIKEAPKG-ESGDGQ LWTSDISED-AAEEMKDAPKG-ESGDGQ LWTSDINEE-AGDEIKEASK---AGEGQ LWTSDINEE-AGDEIKEASK---AVEGQ LWTSDTNED-DVDEIKEAPAPKESGDGQ LWTS DANDD-GGDE I KEAAAPKEPGDQ-

Figure 2 - Alignment of the deduced amino acid sequences of sugarcane expressed sequence tag (EST) clusters SCCCLR1022D05.g, SCCCRZ1001D02.g and SCBFLR1026E02.g with 14-3-3 proteins from Oryza sativa 14-3-3 (gi|7271253), GF14-c (gi|7435022), GF14-b (gi|7435021), and GF14-d (gi|7435023), Zea mays GF14-6 (gi|1345587) and GF14-12 (gi|1345588), Hordeum vulgare 14-3-3 (gi|7435015) and 14-3-3b (gi|2492487), Fritillaria agrestis GF14 (gi|2921512); Lilium longiflorum 14-3-3 (gi|12229593), Triticum aestivum TaWIN1 (gi|9798603). 
maker.pl). Once the corresponding 14-3-3 protein sugarcane cluster was obtained, it was aligned by the BLASTX program to the NCBI protein to check the sequence. Nucleotide and protein sequence alignments were built using the Clustal X (v.1.81) multiple sequence alignment program (Thompson et al., 1997).

\section{RESULTS AND DISCUSSION}

Three EST clusters (SCCCLR1022D05.g, SCCCRZ 1001D02.g and SCBFLR1026E02.g) similar to 14-3-3 proteins were found in the sugarcane EST genome project database. Cluster SCCCLR1022D05.g was similar to the 14-3-3-like GF14-6 protein of Zea mays (gi|1345587), whereas clusters SCCCRZ1001D02.g and SCBFLR1026 E02.g were similar to the 14-3-3-like GF14-c protein of Oryza sativa (gi|7435022). The 14-3-3 proteins were expressed in almost all sugarcane libraries constructed from cDNAs from different plant organs (meristem, callus, flower, bud, leaves, root, stem, seed) and from plantlets infected with bacteria (Glucoacetobacter diazotroficans and Herbaspirillum rubrisubalbicans). The sugarcane 14-3-3 clusters consisted of different cDNAs from different organs (Figure 1a, b and c), whereas 14-3-3 clusters are generally regarded as being specific to a specific tissue or organ (Daugherty et al., 1996). Cluster SCCCLR1022D05.g was present in cDNAs from several tissues but showed more reads in leaves and leaf-roll (Figure 1a). The highest read number of cluster SCCCRZ1001D02.g was from flowers and meristems (Figure 1b) while for cluster SCBFLR1026 E02.g the highest read number was from flowers (Figure $1 \mathrm{c})$.

Clusters SCCCLR1022D05.g, SCCCRZ1001D02.g and SCBFLR1026E02 were 1,215 bp, 1,149 bp and 1,274 bp long, respectively. Cluster SCCCLR1022D05.g had a single open reading frame (ORF) of $783 \mathrm{bp}$ encoding a polypeptide of 261 amino acids while clusters SCCCRZ 1001D02.g and SCBFLR1026E02.g both had an ORF of 786 bp encoding 256 amino acid residues (Figure 2). All of the clusters had an in-frame stop codon in the 5' untranslated region and a putative polyadenylation signal in the 3 ' untranslated region. The sugarcane 14-3-3s were polymorphic in their nucleotide sequences, with the main difference between the sugarcane clusters and the maize and rice 14-3-3 nucleotide sequences occurring in the untranslated regions at the 5 and 3 ends.

The translated sequences of the sugarcane clusters differed mainly at the third nucleotide codon position of the sequences. There were few differences in the deduced sequences of the three clusters (Figure 2). Clusters SCBFLR 1026E02.g and SCCCRZ1001D02.g were more closely related to rice 14-3-3 (gi|7435022) than to cluster SCCCLR 1022D05.g (Figure 3). Cluster SCBFLR1026E02.g had a glutamine at position 82 , a threonine at position 150 and an isoleucine at position 126, whereas cluster SCCCRZ1001 D02.g and rice 14-3-3 had leucine, alanine and leucine, re-

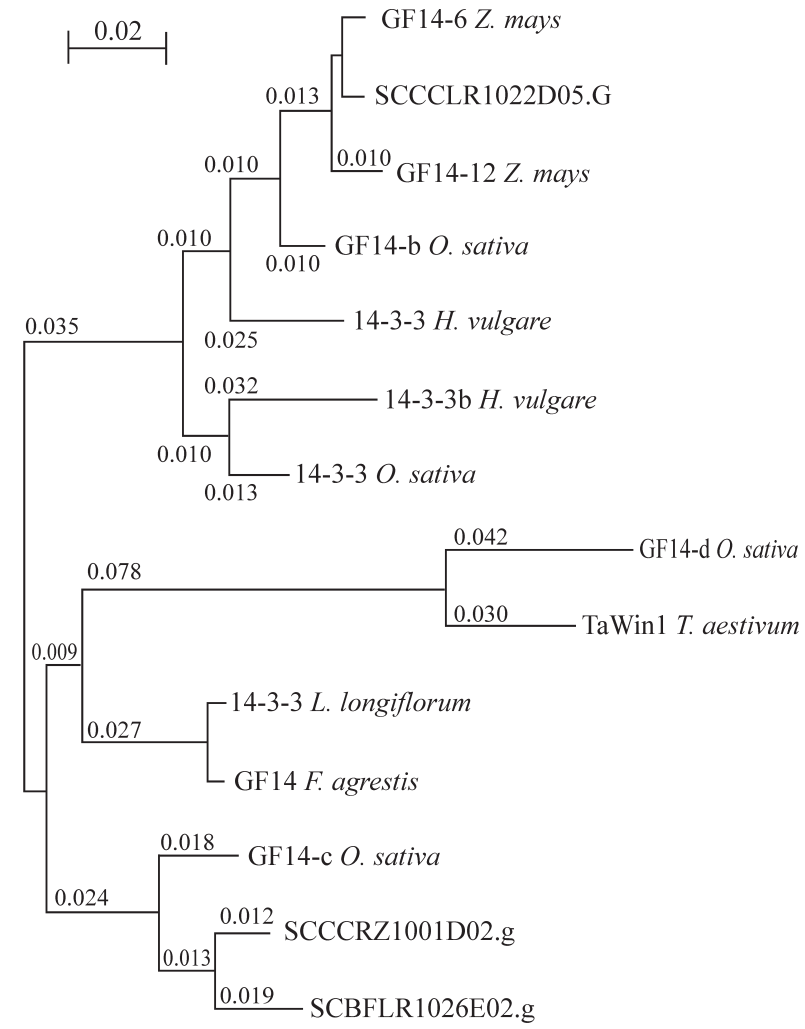

Figure 3 - Dendrogram showing the distance relationships between 14-3-3 amino acid sequences of sugarcane clusters SCCCLR1022D05.g, SCCCRZ1001D02.g and SCBFLR1026E02.g and 14-3-3 proteins of mai$\mathrm{ze}$, rice and barley. The sequence distance tree was calculated using the neighbor-joining algorithm.

spectively, at the same positions (Figure 2). At position 131, cluster SCBFLR1026E02.g had an isoleucine whereas cluster SCCCRZ1001D02.g and rice 14-3-3 had alanine and leucine, respectively. Cluster SCCCLR1022D05.g was more closely related to maize 14-3-3 (gene gi|1345587) than to the other two sugarcane 14-3-3 clusters (Figure 3). Indeed, compared to clusters SCCCRZ1001D02.g and SCBFLR1026E02.g, cluster SCCCLR1022D05.g was five amino acid residues longer (Figure 2). Differences in amino acid composition and sequence could also explain the 14-3-3 isoforms reported by van Heusden et al. (1996) for Arabidopsis thaliana.

In our study, three full length 14-3-3-like proteins were found in sugarcane, with cluster SCCCLR1022D05.g showing 99\% similarity to the 14-3-3-like protein of Zea mays (gene gi|1345587) and the deduced amino acid sequence of clusters SCCCRZ1001D02.g and SCBFLR1026 E02.g showing high similarity (96\% and 94\%, respectively) to the 14-3-3 protein of rice (gene gi|7435022).

\section{RESUMO}

Seqüências completas de três cDNAs que codificam proteínas 14-3-3 de cana-de-açúcar (Saccharum officinarum) foram encontradas no projeto genoma EST de cana-de-açúcar. As proteínas codificadas por essas seqüên- 
cias foram identificadas baseando-se no agrupamento de ESTs de cana-de-açúcar e, três "clusters" (SCCCLR1022 D05.g, SCCCRZ1001D02.g e SCBFLR1026E02.g) foram similares a proteínas 14-3-3 de outras monocotiledôneas. $\mathrm{O}$ cluster SCCCLR1022D05.g apresentou similaridade de 99\% com a proteína 14-3-3 de milho (gi|1345587) e, os clusters SCCCRZ1001D02.g e SCBFLR1026E02.g foram similares a proteína 14-3-3 de arroz (gi|7435022), 96\% e 94\%, respectivamente. Embora proteínas 14-3-3 têm sido relatadas como sendo específicas a organismos, tecidos e órgãos, todos os "clusters" de cana-de-açúcar correspondentes a 14-3-3 foram provenientes de cDNAs advindos de diferentes tecidos.

\section{REFERENCES}

Aitken, A., Collinge, D.B., van Heusden, G.P.H., Isobe, T., Roseboom, P.H., Rosenfeld, G. and Soll, J. (1992). 14-3-3 proteins: a highly conserved, widespread family of eukaryotic proteins. Trends Biochem. Sci. 17: 498-501.

Alam, R., Hachiya, N., Sakaguchi, M., Kawabata, S., Iwanago, S., Kitajima, M., Mihara, K. and Omura, T. (1994). cDNA cloning and characterization of mitochondrial import stimulation factor (MSF) purified from rat Liver cytosol. Biochem. J. 116: 416-425.

Bachmann, M., Huber, J.L., Liao, P.C., Gage, D.A. and Huber, S.C. (1996b). The inhibitor of phosphorylated nitrate reductase from spinach (Spinacea oleracea) is a 14-3-3 protein. FEBS Lett. 387: 127-131.

Bachmann, M., Shiraishi, N., Campbell, W.H., Yoo, B.-C., Harmon, A.C. and Huber, S.C. (1996a). Identification of ser-543 as the major phosphorylation site on spinach leaf nitrate reductase. Plant Cell. 8: 505-517.

Baunsgaard, L., Fuglsang, A.T., Jahn, T., Korthout, H.A.A.J., de Boer, A.H. and Palmgren, M.G. (1998). The 14-3-3 proteins associate with the plant plasma membrane $\mathrm{H}^{+}$-ATPase to generate a fusicoccin binding complex and a fusicoccin responsive system. Plant J. 13: 661-671.

Bihn, E.A., Paul, A.-L., Wang, S.W., Erdos, G.W. and Ferl, R.J. (1997). Localization of 14-3-3 proteins in the nuclei of arabidopsis and maize. Plant J. 12: 1439-1445.

Brandt, J., Thordal-Christensen, H., Vad, K., Gregersen, P.L. and Collinge, D.B. (1992). A pathogen-induced gene of barley encodes a protein showing high similarity to a protein kinase regulator. Plant J. 2: 815-820.

Camoni, L., Harper, J.F. and Palmgren, M.G. (1998). 14-3-3 proteins activate a plant calcium-dependent protein kinase (CDPK). FEBS Lett. 430: 381-384.

Daugherty, C.J., Rooney, M.F., Miller, P.W. and Ferl, R.J. (1996). Molecular organization and tissue-specific expression of an Arabidopsis 14-3-3 gene. Plant Cell 8: 1239-1248

Douglas, P., Moorhead, G., Hong, Y., Morrice, N. and MacKintosh, C. (1998). Purification of a nitrate reductase kinase from Spinacea oleracea leaves, and its identification as a calmodulin-domain protein kinase. Planta 206: 435-442.

Douglas, P., Pigaglio, E., Ferrer, A., Halford, N.G. and MacKintosh, C. (1997). Three spinach leaf nitrate reductase hydroxy-3-methylglutaryl-CoA reductase kinases that are regulated by reversible phosphorylation and/or $\mathrm{Ca}^{2+}$ ions. Biochem. J. 325: 101-109.
Douglas, P., Morrice, N. and MacKintosh, C. (1995). Identification of a regulatory phosphorylation site in the hinge 1 region of nitrate reductase from spinach (Spinacea oleracea) leaves. FEBS Lett. 337: 113-117.

Ferl, R.J. (1996). 14-3-3 proteins and signal transduction. Ann. Rev. Plant Physiol. Plant Mol. Biol. 47: 49-73.

Ford, J.C., Al-Khodairy, F., Fotou, E., Sheldrick, K.S., Griffiths, D.J.F. and Carr, A.M. (1994). 14-3-3 protein homologs required for the DNA damage checkpoint in fission yeast. Science 265: 533-537.

Foyer, C.H., Valadier, M.H. and Ferrario, S. (1995). Co-regulation of nitrogen and carbon assimilation in leaves. In: Environment and Plant Metabolism. (Smirnoff, N., ed.) BIOS Scientific Publishers, Oxford, pp.17-33.

Fu, H., Coburn, J. and Collier, R.J. (1993). The eukaryotic host factor that activates exoenzyme $\mathrm{S}$ of Pseudomonas aeruginosa is a member of the 14-3-3 protein family. Proc. Natl. Acad. Sci. U.S.A. 90: 2320-2324.

Hachiya, N., Komiya, T., Alam, R., Iwahashi, J., Sakaguchi, M., Omura, T. and Mihara, K. (1994). MSF, a novel cytoplasmic chaperone which functions in precursor targeting to mitochondria. EMBO J. 13: 5146-5154.

van Heusden, G.P.H., van der Zanden, A.L., Ferl, R.J. and Steensma, H.Y. (1996). Four Arabidopsis thaliana 14-3-3 protein isoforms can complement the lethal yeast bmh1 and bmh2 double disruption. FEBS Lett. 391: 252-256.

van Heusden, G.P.H., Wenzel, T.J., Lagendijk, E.L., Steensma, H.Y. and Van den Berg, J.A. (1992). Characterization of the yeast BMH1 gene encoding a putative protein homologous to mammalian protein kinase II activators and protein kinase C inhibitors. FEBS Lett. 302: 145-150.

Hirsch, S., Aitken, A., Bentch, U. and Soll, J. (1992). A plant homologue to mammalian brain 14-3-3 protein and protein kinase C inhibitor. FEBS Lett. 296: 222-224.

Jahn, T., Fuglsang, A.T., Olsson, A., Bruntrup, I.M., Collinge, D.B., Volkmann, D., Sommarin, M., Palmgren, M.G. and Larsson, C. (1997). The 14-3-3 protein interacts directly with the C-terminal region of the plant plasma membrane $\mathrm{H}$ (+) - ATPase. Plant Cell 9: 1805-1814.

Kaiser, W.M. and Förster, J. (1989). Low $\mathrm{CO}_{2}$ prevents nitrate reduction in leaves. Plant Physiol. 91: 974.

Knetsch, M.L., van Heusden, G.P., Ennis, H.L., Shaw, D.R., Epskamp, S.J. and Snaar-Jagalska, B.E. (1997). Isolation of a Dictyostelium discoideum 14-3-3 homologue. Biochim. Biophys. Acta 1357: 243-248.

MacKintosh, C. (1998). Regulation of plant nitrate assimilation: from ecophysiology to brain proteins. New Phytol. 139: 153-159.

Martens, G.J.M., Piosik, P.A. and Danen, E.H.J. (1992). Evolutionary conservation of the 14-3-3 protein. Biochem. Biophys. Res. Commun. 184: 1456-1459.

Martin, H., Rostas, J., Patel, Y. and Aitken, A. (1994). Subcellular localisation of 14-3-3 isoforms in rat brain using specific antibodies. J. Neurochem. 63: 2259-2265.

Moore, B.W. and Perez, V.J. (1967). Specific acidic proteins of the nervous system. In: Physiological and Biochemical Aspects of Nervous Intergration. (F.D. Carlson, ed.). MA: Prentice-Hall, Woods Hole, pp. 343-359.

Moorhead, G., Douglas, P., Morrice, N., Scarabel, M., Aitken, A. and MacKintosh, C. (1996). Phosphorylated nitrate re- 
ductase from spinach leaves is inhibited by 14-3-3 proteins and activated by fusicoccin. Curr. Biol. 6: 1104-1113.

Morgan, A. and Burgoyne, R.D. (1992). Interaction between protein kinase $\mathrm{C}$ and Exo1 (14-3-3 protein) and its relevance to exocytosis in permeabilized adrenal chromaffin cells. Biochem. J. 286: 807-811.

Schultz, T.F., Medina, J., Hill, A. and Quatrano, R.S. (1998). 14-3-3 proteins are part of an abscisic acid-VIVIPAROUS1 (VP1) response complex in the Em promoter and interact with VP1 and EmBP1. Plant Cell 10: 837-847.

Sreenivasan, T.V, Ahloowalia, B.S. and Heinz, D.J. (1987). Cytogenetics. In: Sugarcane Improvement Through Breeding (D.J. Heinz ed.), Elsevier, Amsterdam, pp. 211-253.

Su, W., Huber, S. and Crawford, N.M. (1996). Identification in vitro of a post-translational regulatory site in the hinge 1 re- gion of Arabidopsis nitrate reductase Plant Cell. 8: 519-527.

Swanson, K.D. and Ganguly, R. (1992). Characterization of a Drosophila melanogaster gene similar to the mammalian genes encoding the tyrosine/tryptophan hydroxylase activator and protein kinase C inhibitor proteins. Gene 113: 183-190.

Thompson, J.D., Gibson, T.J., Plewniak, F., Jeanmougin, F. and Higgins, D.G. (1997). The ClustalX windows interface: flexible strategies for multiple sequence alignment aided by quality analysis tools. Nuclei Acids Res. 25: 4876-4882.

Toker, A., Ellis, C.A., Sellers, L.A. and Aitken, A. (1990). Protein kinase C inhibitor proteins. FEBS Lett. 191: 421-429.

de Vetten, N.C. and Ferl, R.J. (1994). Two genes encoding GF14 (14-3-3) proteins in Zea mays. Plant Physiol. 106: 1593-1604.

de Vetten, N.C., Lu, G. and Ferl, R.J. (1992). A maize protein associated with the G-Box binding complex has homology to brain regulatory proteins. Plant Cell 4: 1295-1307. 